\author{
Research Article
}

\title{
Export Barriers for SMEs from Emerging Market: A Model of Analysis for Non-Tech Companies
}

\author{
Cristiano Morini ${ }^{1}$ \\ Mario Cesar Barreto Polis ${ }^{1}$ \\ Dirceu da Silva ${ }^{2}$ \\ Edmundo Inacio Junior ${ }^{1}$ \\ ${ }^{1}$ Universidade de Campinas, Limeira, SP, Brazil \\ ${ }^{2}$ Universidade de Campinas, Campinas, SP, Brazil
}

Received 13 November 2020. This paper was with the authors for three revisions. Accepted 07 October 2021. First published online 05 November 2021.

Editors-in-Chief: Carlo Gabriel Porto Bellini (ID) (Universidade Federal da Paraiba, Brazil) Ivan Lapuente Garrido (ID) (Universidade do Vale do Rio dos Sinos, Brazil)

Associate Editors: Fábio Lotti Oliva (1D) (Universidade de São Paulo, São Paulo, SP, Brazil);

Cristina Villar(ID) (Universitat de València, Valencia, Spain)

Reviewers: Maria Laura F. Mac Lennan (D) (Universidade Ibirapuera, São Paulo, SP, Brazil) and two anonymous reviewers

Editorial assistants: Kler Godoy and Simone Rafael (ANPAD, Maringá, PR, Brazil) 


\section{ABSTRACT}

This research seeks to enrich the existing theories by analyzing what are the barriers affecting the export process of small and medium-sized non-tech companies in emerging markets, while simultaneously examining the relationship between internal and external barriers in this context. Non-tech companies are characterized by little knowledge and limited resources. How could this kind of company reach the global market? What barriers hinder the exporting process the most? A confirmatory factor analysis was carried out, and the validated model based on 71 responses obtained was adjusted in a selected sector. The results suggest that the governmental and sociocultural barriers are the most significant from the perspective of external barriers, while market barriers and the manager's personal dimensions have greater significance from the perspective of internal barriers. Our paper offers a theoretical contribution by developing a measurement model (a) testing the existing barriers simultaneously with the managerial/entrepreneurial barriers and with (b) the focus on non-tech firms. For practitioners, the identification of barriers can be useful to foster specific actions in terms of public policies, in addition to internal actions focused on the development of the managers' capacities.

Keywords: barriers; export; validation instrument; small and medium-sized enterprises; nontechnological based company

JEL Code: M16 


\section{INTRODUCTION}

According to Al-Hyari, Al-Weshah, and Alnsour (2012), internationalization brings a significant increase in business opportunities. In order to succeed, export firms must overcome the barriers to internationalization. Studies regarding the internationalization of firms from emerging markets (EM) are not quite common in the literature (Al-Hyari, Al-Weshah, \& Alnsour, 2012; Bianchi, Carneiro, \& Wickramasekera, 2018; Revindo, Gan, \& Massie, 2019; Roy, Sekhar, \& Vyas, 2016; Senik, Isa, Sham, \& Ayob, 2014), especially focusing on non-tech companies. This kind of companies is characterized by little knowledge and limited resources. They are necessitydriven in terms of entrepreneurship and barely intend to export.

We focused on this content because three quarters of the countries in the world are not developed (Silver, 2003). Most of the firms in those countries are not from the tech sector. Examining to what extent barriers hinder the export process may allow enough fuel to face the problem, thus contributing to ameliorate the economic growth and producing some efficiency in these firms.

Academic literature covers a variety of internationalization studies, but the process of identifying barriers to emerging markets from small and medium enterprises (EM-SMEs) is not wellunderstood regarding non-tech companies from a comprehensive perspective, which is understood as a wider and deeper one, encompassing aspects from the market as well as from the firm (mainly related to the human aspect).

According to Dabić et al. (2020), there is a clear gap in the literature regarding emerging markets in the internationalization process. They also stand to the gap related to low-tech industries, as they emphasize a possible risk that the studies provided by scholars, policymakers, and practitioners are exclusively tailored toward high-tech firms. Some studies focus on the barriers to internationalization with regard to information and marketing (Hosseini, Fallon, Weerakkody, \& Sivarajah, 2019), to resilience and non-resilience (Rahman \& Mendy, 2019), to human- and technology-oriented (Mendy \& Rahman, 2019), and to exporting barriers from developed countries (Tan, Brewer, \& Liesch, 2018).

Leonidou's (2004) work is a reference because he analyzed and listed 39 export barriers from 32 empirical works, with special implications for small businesses. His paper became a high-cited reference in this content.

Since Leonidou's (2004) reference paper was published, we added papers that analyze mainly barriers or some marginal barriers by examining the export stimuli. Our version updated that list and added a managerial/entrepreneurial dimension, testing all dimensions analyzed together. The managerial dimension concerns psychological aspects of decision-makers, as cognitive style, proactiveness, and tolerance to ambiguity (Acedo \& Galán, 2011). In Acedo and Galán (2011), some variables of the theory of planned behavior (TPB) are used to stress the role played by the manager as a required condition to understand the behavior and results of the export stimuli of the firm.

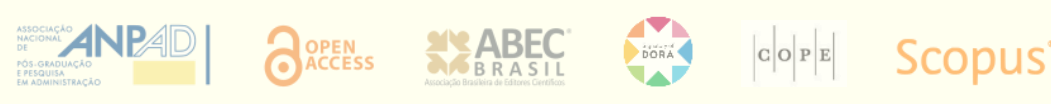


Our paper offers a contribution by developing a measurement model (a) testing the existing barriers simultaneously with the managerial/entrepreneurial barriers and with (b) the focus on non-tech firms. The existing studies are focused on specific aspects of barriers that may hinder internationalization, but they do not consider personal characteristics either as a barrier or in the context of non-tech firms. This is new and may contribute to the process to evolve the knowledge, adding a new layer of analysis to the existing ones.

Even though some studies split the barriers into more dimensions (Cardoza \& Fornes, 2011; Bianchi et al., 2018), we opted to maintain the taxonomy of internal and external barriers. What is new in our paper it that we added a managerial dimension as an internal barrier (firm's perspective), and we examine those barriers in a non-tech based firm of the emerging market. These lenses either were not explicitly mentioned in other studies or were not analyzed in a comprehensive and combined way. How could EM-SMEs reach the global market? What barriers hinder the export process the most? After doing the literature review, we raised nine hypotheses that have not been analyzed altogether before.

Thus, the objective of this article is to analyze the perception of managers and decision-makers of EM-SMEs about the barriers to exporting, contributing to add a new dimension and examining a new combined model of analysis, since the seminal paper published by Leonidou (2004). The literature review identified almost only studies related to internationalization barriers in tech companies (Arroteia \& Hafeez, 2021; Cahen, Lahiri, \& Borini, 2016), and little is done concerning non-tech industries from EM. The research question that came up from the literature review is: What are the export barriers for non-tech EM-SMEs? Which aspects does it encompass? We contribute to answering these questions.

By answering the RQs, we propose a new model of analysis, including a managerial dimension to the existent ones. The Leonidou's (2004) reference model was evolving from then to 2020 (as also shown by Narayanan, 2015). The results of our work show that, despite the relevant role of the governmental aspect, it is not the only one to blame. Internal barriers, associated with the company and its manager's individual capabilities, also hinder this process.

The main theoretical contribution of this study is twofold: (a) it revealed the hitherto neglected role of managerial dimension in the set of barriers, thus helping (b) to evolve the understanding of the barriers in a novel model, by bridging human and market dimensions in the context of the non-tech EM-SMEs. This may provide (c) arguments for policymakers to (re)act in this context. Understanding the export process, opportunities, problems, and the challenges faced by SMEs is an opportunity for policymakers and researchers (Paul, 2020). To this end, a model was proposed, developed, and validated in a selected industrial sector. Unlike other studies, like Luo and Tung (2007), the focus was not on EM-MNEs (multinational enterprises from emerging markets), which go abroad as a springboard to exploit their advantages in other countries. MNEs have developed expertise in mass production and they have to exploit innovation by scale-up. The export process of the SMEs is quite different in the willingness of achieving the target markets. Therefore, the focus was neither in MNEs nor in tech companies.

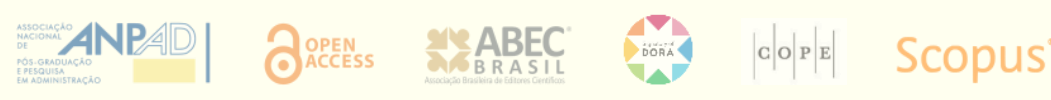


We propose a comprehensive model by enriching the theoretical discussion, calibrating the analysis to the non-tech EM-SMEs. This paper focuses on the direct export process regarding the internationalization, for which the export process is the first and most common way. The research was carried out in the Brazilian context.

This article begins with a discussion of export barriers mainly from the EMs' firms. Then we describe a survey undertaken in Brazilian SMEs. A confirmatory factor analysis was taken using a structural equation model applied to the set of items used to measure the exporting barriers. We used the dimensions captured from the literature review and combined them in a novel model. We analyzed and discussed the results. We then draw implications relating to EM-SMEs in non-tech companies. We conclude with the limitations and suggestions for future works, emphasizing our contribution to evolving the SME internationalization theory.

\section{LITERATURE REVIEW}

We used the European Union (EU) criterion to classify companies into micro-, small and medium-sized enterprises. In general, there are several ways to classify the size of a company, each of them designed by federal agencies for their own purposes. Economic and fiscal criteria generally use the number of staff employed and the company's revenue, but even between these two, there is great variability. We opted for the European Union's criterion as it allows international comparisons. It considers that a micro-sized enterprise would have up to nine employed persons; a small-sized enterprise would have between 10 and 49; and a medium-sized enterprise would have between 50 and 249 (Organisation for Economic Co-operation and Development [OECD], 2005).

We will conduct the literature review by two main streams (originally proposed by Leonidou, 2004), both focusing on SMEs: (a) internal and external barriers to the internationalization of companies; and (b) other approaches.

Since the work published by Leonidou (2004), several studies came up identifying internal and external barriers to internationalization, mainly in SMEs (Cardoza \& Fornes, 2011; Castaño, Méndez, \& Galindo, 2016; Ciravegna, Majano, \& Zhan, 2014; Gardó, García, \& Descals, 2015; Kunday \& Şengüler, 2015; Mohr \& Shoobridge, 2011; Oliveira, Leite, Shibao, \& Lucato, 2017; Roux \& Bengesi, 2014; Roy et al., 2016).

In addition, among those that have gone international, the ability to innovate and seek new technologies stands out (Amorós, Basco, \& Romaní, 2016). Companies that went abroad explored resources by their rareness, value, and most of the time non-imitable characteristics (Barney, 1991). While updating and technologically improving production processes reduce the cost of operations, product and service innovations allow them to enter competitive environments in the international market (Buse, Tiwari, Herstatt, 2010; Cahen et al., 2016; Kamakura, Ramón-Jerónimo, \& Gravel, 2012; Rahman, Uddin, \& Lodorfos, 2017). However, studies regarding innovation and tech companies will not be focused on this paper.

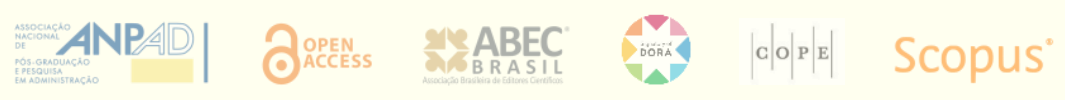


The barriers can also be associated with cultural factors, such as language, methods of 'doing' business, culture, ideology (Colapinto, Gavinelli, Zenga, \& Gregorio, 2015; Krakawer, Jussani, \& Vasconcellos, 2013), and family members (in the case of family SMEs, such as their reluctance to go international) (Meneses, Coutinho, \& Pinho, 2014; Merino, Monreal-Pérez, \& SánchezMarín, 2015), as well as the difficulty in relinquishing (even partially) control to managers who can enable the international experience (Plakoyiannaki, Kampouri, Stavraki, \& Kotzaivazoglou, 2014).

Since the publication of Leonidou's (2004) work, different dimensions were added in the inventory of internal and external/push and pull causes that may hinder the export process. Nonetheless, the dimension related to the manager either is analyzed individually and detached from other possible causes (Acedo \& Galán, 2011) or it is focused in a context of tech companies (Cahen et al., 2016; Yan, Wickramasekera, \& Tan, 2018). The study of Senik, Isa, Sham and Ayob (2014) analyzes the EM-SMEs, through the Malaysian perspective, and develops a generic model based on pulling-pushing factors. This may be the only study that considers a comprehensive model as we propose in our paper. Despite this, the method used by Senik et al. (2014) is an expert panel with 32 participants, using descriptive statistics. We deepened the research method, in a model with a quantitative approach, in a comprehensive analysis.

Acedo and Galán (2011) highlight the psychological aspects of decision-makers in SMEs. The authors argue that the perception of export opportunities and risks influences the decision to enter foreign markets. More proactive individuals have more favorable perceptions of foreign markets than less proactive individuals. Tan, Brewer and Liesch (2018) use the Luostarinen's concept (1979) of 'lateral rigidity' as part of the export decision behavior, because of limited perception, satisfaction to the domestic market, lack of international experience, risk aversion, and poor preparedness. They utilize a sample of Australian SMEs to clarify the role played by the lateral rigidity, as a latent variable. They consider that manager's behavior will have an effect on the internationalization of the firm. Despite this, Senik et al. (2014) emphasize that the process of internationalization from a developed economy differs from the emerging one.

Regarding external factors, Rahman, Uddin and Lodorfos (2017) identified that one of the main barriers of this nature refers to socioeconomic actions, with emphasis on economic and financial differences. In relation to the financial barrier, the lack of credit and the high cost of obtaining it, in addition to the lack of accessible financing, are key factors decreasing the operational capacity of MSMEs, as they prevent them from both increasing productivity and maintaining productive capacity (Deuba, 2015; Kozlova, 2014).

The list of external factors also includes those related to politicians (Caiazza, 2016), since actions to promote internationalization - carried out by agents such as trade associations and chambers of commerce with subsidies from federal and local governments and the support of institutions - help deepening the government-academia-company partnership (Etzkowitz \& Gullbrandsen, 1999). 
Finally, other approaches refer to the institutional factor and the support of organizations for internationalization (Cahen et al., 2016; Lejárraga \& Oberhofer, 2015; Salvador, Villechenon, $\&$ Rizzo, 2014). A significant aspect related to the institutional factor refers to the degree of bureaucracy in these companies, as the excessive number of regulation, legal procedures, and tariffs inhibit the internationalization process (Kuivalainen, Sundqvist, Saarenketo, \& McNaughton, 2012; Makhmadshoev, Ibeh, \& Crone, 2015). Zhu, Warner and Sardana (2020) analyzed internationalization from EM-SMEs, considering exports from China and India, by developing a framework to investigate the factors influencing the choice of destination for internationalization. Shih and Wickramasekera (2011) emphasize the SME's export involvement by enhancing factors and inhibiting factors, what is corroborated by Revindo, Gan and Massie (2019), which analyze the SME's export engagement in Indonesia. Shih and Wickramasekera (2011) deal with enhancing and inhibiting factors for the export from Taiwanese SMEs, focusing on the electronics sector (high tech sector).

Considering the sixteen-year history of works since Leonidou's paper (2004), we were able to identify the following research question as a gap in the literature: What aspects hinder the export process (not the internationalization itself) of non-tech EM-SMEs? To answer this main RQ (and other RQs derived from), we build an expanded novel model considering a new combination of dimensions (a) and validating the model in a context of non-tech EM-SMEs in Brazil (b).

\section{Proposed model}

Based on what we have told in the previous section and, in particular, on the studies by Al-Hyari et al. (2012), Senik et al. (2014), and Roy, Sekhar and Vyas (2016), which focus on the export process from emerging markets $(E M)$, this paper also uses two major dimensions $\left(2^{\text {nd }}\right.$ order constructs), namely, internal (INT) and external (EXT) barriers to exporting, a classification that is also adopted by several other studies as mentioned before (as Hessels \& Parker, 2013; Leonidou, 2004; Morgan, 1997).

In addition to the factors originally employed by Al-Hyari et al. (2012) and Roy et al. (2016), the model was also developed based on studies identified in the literature review (Deuba, 2015; Gardó et al., 2015; Hessels \& Parker, 2013; Kahiya, 2017; Morgan, 1997). An integrative conceptual new model was proposed, whose items are listed in Figures 1a and 1b (equivalent to the questions in the questionnaire). 


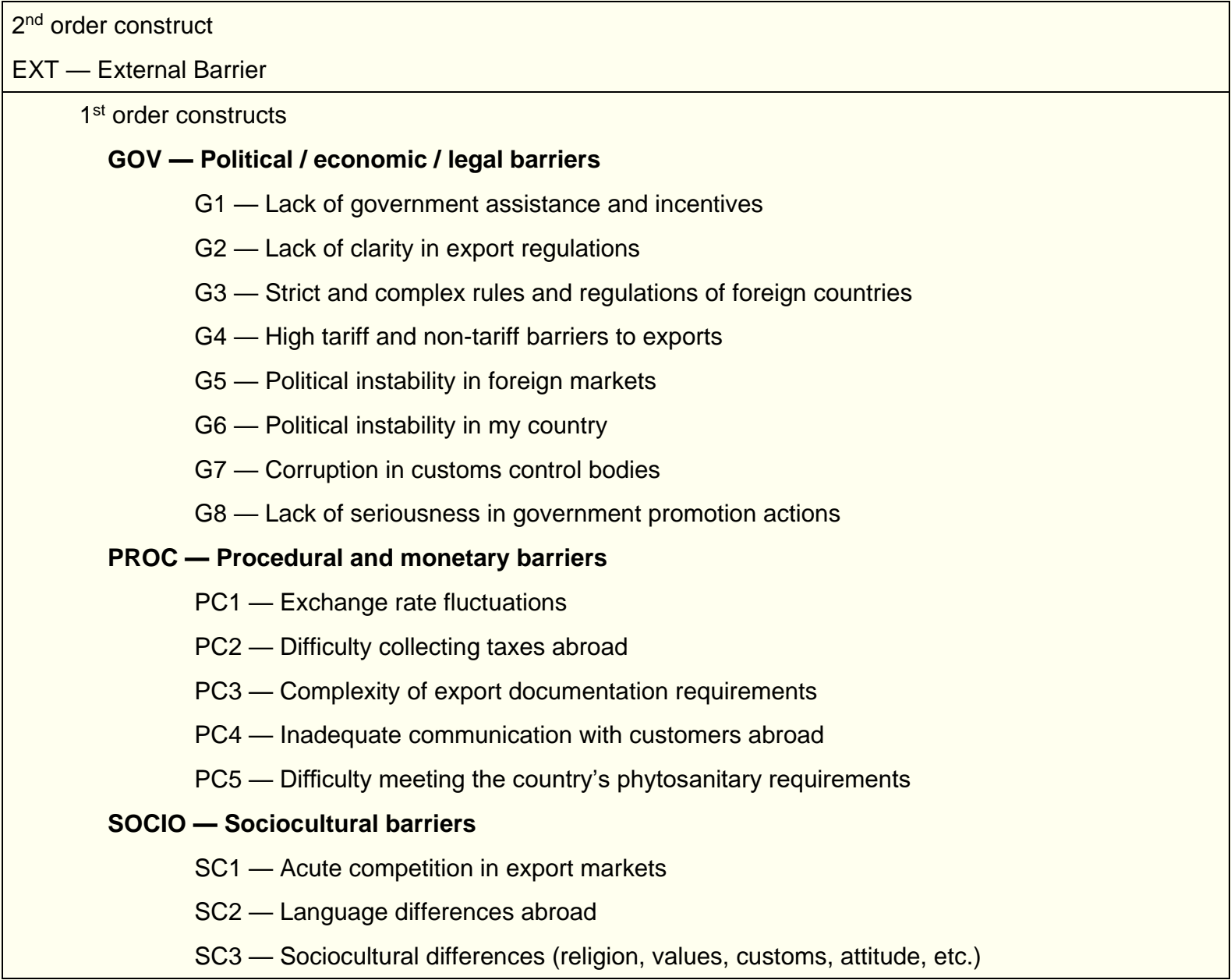

Figure 1a. Detailed information about constructs and items of the model (that originated questions in the questionnaire). 


$$
\begin{aligned}
& 2^{\text {nd }} \text { order construct } \\
& \text { INT }- \text { Internal Barrier }
\end{aligned}
$$

INFO - Informational barriers

11 - Insufficient information on foreign markets

12 - Difficulty identifying and contacting potential customers

13 - Difficulties gaining access to data sources

\section{MNG - Management barriers}

GT1 - Lack of time to deal with exports

GT2 - Inadequate/inexperienced export personnel

GT3 - Difficulty finding a reliable representative abroad

GT4 - Lack of time and personnel

GT5 - Lack of production capacity

\section{FIN — Financial barriers}

F1 - High cost of capital to finance exports

F2 - Lack of financial resources to finance exports

F3 - Difficulty giving credit to customers in international markets

F4 - Long liquidity period when receiving payment from abroad

\section{MKT — Market barriers}

MK1 - Difficulty adapting export products

MK2 - Difficulty meeting export quality requirements

MK3 - Lack of competitive pricing for customers in foreign markets

MK4 - Complexity of foreign distribution channels

MK5 — Difficulty offering adequate after-sale services

MK6 - Difficulty effectively controlling intermediaries

MK7 - Difficulty exporting to countries where the company has no warehouse

MK8 - High transportation cost / lack of transportation quality

MK9 - High cost of international insurance

ENT - Barriers to entrepreneurship

E1 - Lack of technological innovation in the company

E2 - Lack of vocation for internationalization

E3 - Relationship conflicts in family business

E4 - Lack of control in new operations

E5 - Risk aversion

E6 - Difficulty transferring responsibilities when the subject is new

Figure 1b. Detailed information about constructs and items of the model (that originated questions in the questionnaire).

The INT and EXT barriers are, therefore, second-order constructs of the model and, as such, do not have items that can be observed or measured based on the respondents' answers. The three constructs related to external barriers are: political, economic, and legal (GOV); procedural and 
monetary (PROC); and sociocultural (SOCIO) aspects. The five constructs related to internal barriers are: informational (INFO); management (MNG); financial (FIN); market (MKT); and entrepreneurship (ENT) aspects. Table 1 shows that all nine research hypotheses follow the same logic, i.e.: construct ' $\mathrm{X}$ ' is positively correlated with construct ' $\mathrm{Y}$ ', and Table 2 clarifies where the hypothesis came from.

Table 1

Model's hypotheses according to the literature review

\begin{tabular}{|c|c|c|c|c|c|}
\hline Hypothesis & $\begin{array}{l}\text { Description } \\
\left.\text { Barrier... ( } 1^{\text {st }} \text { order construct }\right)\end{array}$ & & $\begin{array}{c}\text { Type of } \\
\text { association }\end{array}$ & \multicolumn{2}{|c|}{ Barrier ( $2^{\text {nd }}$ order construct) } \\
\hline $\mathrm{H} 1$ & Political, economic, and legal & GOV & \multirow{10}{*}{$\begin{array}{c}\text { is positively } \\
\text { correlated } \\
\text { with }\end{array}$} & \multirow{3}{*}{ External } & \multirow{3}{*}{ EXT } \\
\hline $\mathrm{H} 2$ & Procedural and monetary & PROC & & & \\
\hline H3 & Sociocultural & SOClO & & & \\
\hline $\mathrm{H} 4$ & Informational & INFO & & \multirow{7}{*}{ Internal } & \multirow{7}{*}{ INT } \\
\hline H5 & Management & MNG & & & \\
\hline $\mathrm{H} 6$ & Financial & FIN & & & \\
\hline $\mathrm{H} 7$ & Market & MKT & & & \\
\hline \multirow[t]{2}{*}{$\mathrm{H} 8$} & Entrepreneurship & ENT & & & \\
\hline & Barrier... ( $2^{\text {nd }}$ order construct $)$ & & & & \\
\hline $\mathrm{H} 9$ & External & EXT & & & \\
\hline
\end{tabular}

Note. Elaborated by the authors.

In Table 2, we can see the hypotheses with their empirical support. Supporting theories regard the resource-based view (Barney, 1991; Jafari-Sadeghi, Mahdiraji, Bresciani, \& Pellicelli, 2021), and the institutional approach (as in Doh, Rodrigues, Saka-Helmhout, \& Makhija, 2017; Stephen, Urbano, \& Hemmen, 2005). We consider these theories may provide conditions to avoid or mitigate difficulties that may hinder internationalization. Difficulties are lack of valuable resources and lack of institutional support, or when institutions fail in aspects of regulation, monitoring, and incentive policies. In the non-tech firm's context, resources are neither valuable nor rare. They can easily be imitable and substitutable. Moreover, non-tech firms from emerging countries deal with institutional voids, whether in the form of malfunctioning or missing institutions. 
Table 2

Matching table: Hypotheses and from where they come (literature review - empirical support)

\begin{tabular}{|c|c|c|c|c|c|c|c|c|c|c|}
\hline Item & Articles & $\mathrm{H} 1$ & $\mathrm{H} 2$ & $\mathrm{H} 3$ & $\mathrm{H} 4$ & $\mathrm{H} 5$ & $\mathrm{H} 6$ & $\mathrm{H} 7$ & $\mathrm{H} 8$ & $\mathrm{H} 9$ \\
\hline 1 & Leonidou, Katsikeas and Piercy (1998) & & & & & & & & & \\
\hline 2 & Leonidou (2004) & & & & & & & & & \\
\hline 3 & Acedo and Galán (2011) & & & & & & & & & \\
\hline 4 & Cardoza and Fornes (2011) & & & & & & & & & \\
\hline 5 & Meneses, Coutinho and Pinho (2014) & & & & & & & & & \\
\hline 6 & Mohr and Shoobridge (2011) & & & & & & & & & \\
\hline 7 & Al-Hyari et al. (2012) & & & & & & & & & \\
\hline 8 & $\begin{array}{l}\text { Kamakura, Ramón-Jerónimo and Gravel } \\
\text { (2012) }\end{array}$ & & & & & & & & & \\
\hline 9 & Senik et al. (2014) & & & & & & & & & \\
\hline 10 & Ciravegna, Majano and Zhan (2014) & & & & & & & & & \\
\hline 11 & Kozlova (2014) & & & & & & & & & \\
\hline 12 & Roux and Bengesi (2014) & & & & & & & & & \\
\hline 13 & $\begin{array}{l}\text { Plakoyiannaki, Kampouri, Stavraki and } \\
\text { Kotzaivazoglu (2014) }\end{array}$ & & & & & & & & & \\
\hline 14 & $\begin{array}{l}\text { Colapinto, Gabinelli, Zenga and Gregorio } \\
\text { (2015) }\end{array}$ & & & & & & & & & \\
\hline 15 & Deuba (2015) & & & & & & & & & \\
\hline 16 & $\begin{array}{l}\text { Merino, Monreal-Pérez and Sánchez- } \\
\text { Marín (2015) }\end{array}$ & & & & & & & & & \\
\hline 17 & Amorós, Basco and Romaní (2016) & & & & & & & & & \\
\hline 18 & Cahen, Lahiri and Borini (2016) & & & & & & & & & \\
\hline 19 & Caiazza (2016) & & & & & & & & & \\
\hline 20 & Castaño, Méndez and Galindo (2016) & & & & & & & & & \\
\hline 21 & Roy et al. (2016) & & & & & & & & & \\
\hline 22 & Kahiya (2017) & & & & & & & & & \\
\hline 23 & Oliveira, Leite, Shibao and Lucato (2017) & & & & & & & & & \\
\hline 24 & Rahman et al. (2017) & & & & & & & & & \\
\hline 25 & $\begin{array}{l}\text { Bianchi, Carneiro and Wickramasekera } \\
\text { (2018) }\end{array}$ & & & & & & & & & \\
\hline 26 & Tan et al. (2018) & & & & & & & & & \\
\hline 27 & Rahman and Mendy (2019) & & & & & & & & & \\
\hline 28 & Revindo et al. (2019) & & & & & & & & & \\
\hline 29 & Chandra, Paul and Chavan (2020) & & & & & & & & & \\
\hline
\end{tabular}

Note. Elaborated by the authors. Articles ordered by year. 


\section{METHOD}

The literature review was carried out in the Web of Science (WoS) and Scopus databases, using the following keywords as basis: internationalization; small and medium enterprises; and barriers. Applying a first filter allowed removing some articles that had no relation to the object of study. Another filter we considered was studies addressed to emerging markets (EM). Sixty papers came up from the WoS database, and 26 were dismissed because they focus only on tech companies, resulting in 34. From the Scopus database, 78 papers came up as result, and 46 remained after the filtering process. Eight papers were duplicated considering the two databases, resulting in 72 analyzed papers.

We specifically committed to review the literature related to EM and SMEs published from 2004 (Leonidou's seminal paper) to 2020 (only some papers used are out of this range).

After raising the hypotheses and creating the constructs, the questionnaire was developed, based on adaptations from previous studies, mainly those by Leonidou (2004), Acedo and Galán (2011), Al-Hyari et al. (2012), Ciravegna et al. (2014), Senik et al. (2014), Roy et al. (2016), and Rahman et al. (2017) (see Figure 2). The Roy's questionnaire, for example, did not bring the managerial dimension. Roy's questionnaire was an updated version from previous studies above mentioned. Then, our questionnaire was applied to managers or decision-makers of Brazilian SMEs, from different sectors. Brazil shows huge diversity in economic regional development. We focused on the companies of the most industrialized region. The responding companies were not only those with exportations, but also companies that had never exported but that intended to, as well as companies that had tried in the past and were not successful.

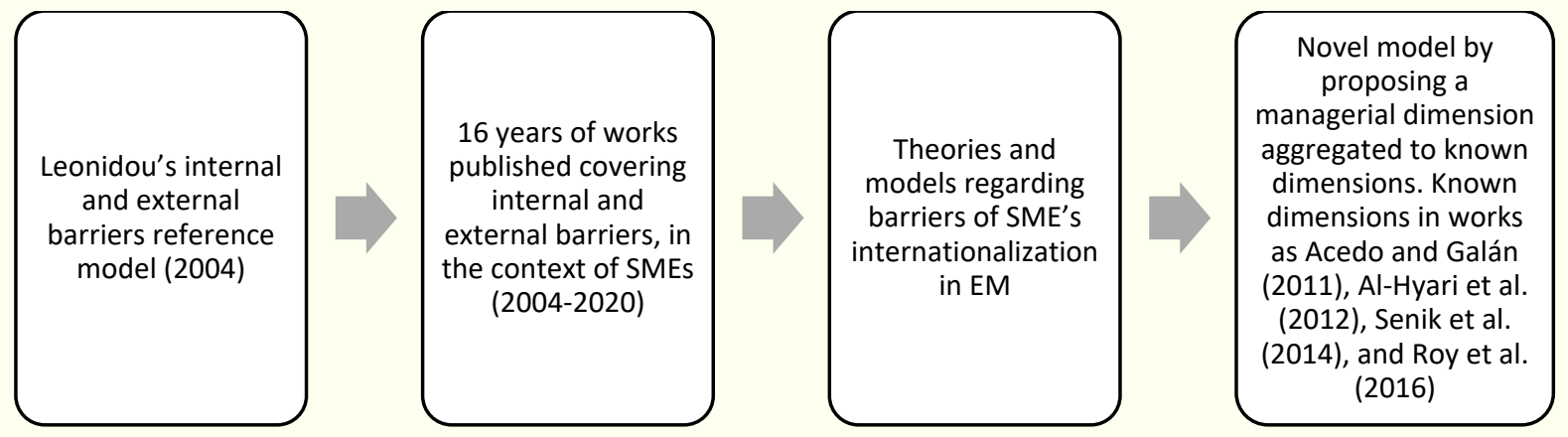

Figure 2. The way to get to the novel model.

Elaborated by the authors.

The participating SMEs (there were no micro-sized companies) were located in the region covered by the PEIEX project (Export Qualification Program from the federal government), an operational center in the region of Campinas, state of São Paulo. The objective of PEIEX, organized by the Export and Investment Promotion Agency (Apex-Brasil), is structuring sectors and strengthening the export base. PEIEX's operational center in Campinas serves, on average, about 250 companies per year. According to data provided by the ComexVis (Comex Stat, 2020), a system of the Ministry of Economy, Industry, Foreign Trade and Services, exports in the region

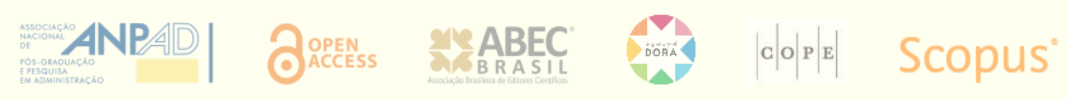


grew by 16.1\% between 2016 and 2017, and by 22.5\% between 2017 and 2018, characterizing it as dynamic in terms of export potential. Campinas is one of the biggest cities in São Paulo, which in turn is the biggest export state, far from the second one. The main airports and ports in Brazil are in São Paulo.

The companies served by PEIEX volunteered to receive training in exports. PEIEX's bank of companies includes companies that already export, and wish to diversify markets, as well as companies that have never exported. In all cases, they intend to export, being at an early, intermediate, or advanced stage of the export process.

The questionnaire was created in Google Forms, and all questions use a Likert scale from one to five. The minimum sample for the study of the instrument's validity and reliability, according to the guidelines of Hair, Black, Babin, and Anderson (2010), and Cohen (1962, 1992), was 55 responses, considering a test power of 0.80 , an effect of 0.15 , and a confidence level of $5 \%$, calculated using the $\mathrm{G}^{*}$ Power software. Of the 250 target companies, 81 agreed to participate, of which 10 were eliminated for not meeting the minimum requirements (failing to provide data or filling out the questionnaire incorrectly). Of the 71 responses obtained, 53 were from small-sized companies, and 18 were from medium-sized ones.

For the analysis of the instrument's validity and reliability, a confirmatory factor analysis (CFA) was carried out in Smartpls ${ }^{\circledR}$ using structural equation modeling (SEM), with partial least squares (PLS) (Hair, Black, Babin, \& Anderson, 2010), via software Smartpls. We use PLS-SEM because there are no normal distributions (Hair, Hult, Ringle, \& Sarstedt, 2014). CFA allows testing the measurement model, i.e., if the observable variables (questions in the questionnaire) are able to properly represent the theoretical constructs (latent variables). A structural analysis of the model was also performed, considering the relations between the latent variables (external barrier positively correlated with the internal barrier) and the second-order variables (constructs that do not have directly measured items), among the constructs associated with the external and internal barriers.

\section{RESULTS}

As the sample was relatively small, a first aspect assessed was the common method bias (CMB), which may come out due to data collection (consistency, social desirability, among many other causes) (Podsakoff, MacKenzie, Lee, \& Podsakoff, 2003). There are at least three techniques for evaluating $\mathrm{CMB}$. Among the methods for detecting $\mathrm{CMB}$, one of the consistent possibilities is to introduce a second order latent variable and link it to all indicators (unmeasured latent method construct - ULMC) (Schwarz, Rizzuto, Carraher-Wolverton, Roldán, \& Barrera-Barrera, 2017). This technique was adapted to the PLS by Liang, Saraf, Hu, and Xue (2007). After the construction of the model with the variable related to the method, the factorial loads were compared and a ratio was reached between the substantive loads (original model) and those due to the $16,67: 1$ method (second order variable). An evaluation of the normality of the data revealed that the values of the substantive loads are not adherent and, therefore, the Mann-

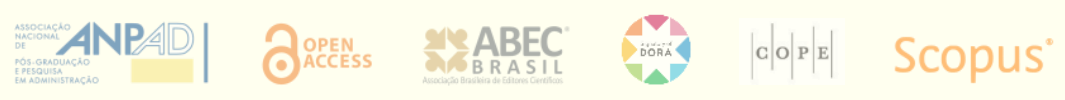


Whitney test was chosen to assess whether this ratio shows significant differences. The test revealed a significant result $Z(U)(1,70)=6.218(p<0.0001)$, indicating that the data collection method did not produce biases.

Also, despite having some criticisms (Podsakoff et al., 2003), we also calculated Harman's single factor test and the result was $28.75 \%$, well below the 50\% reference value (Fuller, Simmering, Atinc, Atinc, \& Babin, 2016). Thus, we confirm again that the presence of bias can be disregarded. The third test was not calculated because we did not have a marker variable in the database.

\section{Measurement model}

According to Hair, Hult, Ringle and Sarstedt (2014), the convergent validity of the measurement model can be conceptualized as "the degree to which a set of measured items really reflects the theoretical latent construct that those items must measure" (Hair et al., 2014, p. 303) This is done by investigating the factor load between the items (questions in the questionnaire) that make up a given construct (latent variable) and itself. The factorial loads must all be statistically significant level $(\alpha=<.05)$, and each construct must have the average variance extracted (AVE) $>$ or $=.50$ or $50 \%$, which means that the construct explains at least $50 \%$ of the sample's variance.

The first analysis, with all the proposed model's 43 initial questions, shows the need of removing some items due to AVE's construct following the expected condition. The eliminations were carried out in steps, after which the algorithm was once again applied to assess the remaining model. The three elimination rounds happened as follows:

$1^{\text {st }}$ round: GOV construct: we eliminated item G3 with a factor load of .410; FIN construct: we eliminated item F1 with a factor load of .548; and MKT construct: we eliminated items MK3 and MK6, with factor loads of .454 and .446, respectively.

$2^{\text {nd }}$ round: GOV construct: we eliminated item G2 with a factor load of 497 ; and MNG construct: we eliminated item GT3 with a factor load of .546.

$3^{\text {rd }}$ round: GOV construct: we eliminated item G4 with a factor load of .524 .

The analysis of Table 3 shows the values of AVE (all large than .50) and the Cronbach's alpha and composite reliability both of which must be equal to or greater than 0.70 (Hair et al., 2014). It also presents the discriminant validity, by the criterion of Fornell and Larcker (1981), according to which the values of the square roots of the AVE (which appear in the hatched diagonal of Table 3) must be higher than the correlations of the respective constructs. All these indicators are presented in Table 3, in which it is possible to verify that the model is adjusted, and its values are adequate. 
Table 3

Quality-adjusted measurement model values

\begin{tabular}{lllllllll}
\hline & ENT & FIN & MNG & GOV & INFO & MKT & PROC & SOCIO \\
\hline ENT & .757 & & & & & & & \\
FIN & .353 & .754 & & & & & & \\
MNG & .673 & .377 & .746 & & & & & \\
GOV & .272 & .323 & .349 & .728 & & & & \\
INFO & .345 & .532 & .390 & .389 & .842 & & & \\
MKT & .439 & .581 & .477 & .609 & .523 & .728 & & .752 \\
PROC & .201 & .314 & .446 & .503 & .472 & .469 & .752 \\
SOCIO & .099 & .365 & .310 & .426 & .411 & .664 & .668 & .797 \\
\hline Cronbach's a & .846 & .629 & .752 & .775 & .790 & .841 & .804 & .717 \\
Composite reliability & .886 & .798 & .831 & .847 & .879 & .883 & .865 & .838 \\
AVE & .572 & .568 & .556 & .529 & .709 & .530 & .565 & .635 \\
\hline
\end{tabular}

Note. The main diagonal in gray shows the square root of AVE. Elaborated by the authors.

\section{Structural model}

Continuing the data analysis, Table 4 presents the Pearson's determination coefficient $\left(\mathrm{r}^{2}\right)$. For Cohen (1988), in the field of social and behavioral sciences, values of $0.26,0.13$, and 0.02 are considered high, medium, and low, respectively. The analysis of the data reveals that the values of the coefficients of determination are high, according to the mentioned criterion.

After the analysis, the blindfolding module of the SmartPLS software was used to calculate StoneGeisser's $\left(Q^{2}\right)$ and Cohen's coefficients $\left(f^{2}\right)$ in order to assess the model's predictive validity and the effect size, respectively (see Table 4). For the model to have predictive validity, all values of $\mathrm{Q}^{2}$ must be greater than zero (Hair et al., 2014), and the effect size was calculated according to the recommendations proposed by Cohen (1988), i.e., $\mathrm{f}^{2}$ values of .02, .15, and .35 are considered low, medium, and moderate, respectively. Table 4 also shows the values of the two indicators mentioned.

Thus, Stone-Geisser's coefficient $\left(\mathrm{Q}^{2}\right)$ shows that all constructs have predictive validity and that ENT, INFO, and MKT have high effect sizes $\left(f^{2}\right), M N G, G O V$, and PROC have medium to high effect sizes, and FIN has a medium effect size. Thus, the constructs have high and medium importance for the model as a whole. 
Table 4

\section{Values of the structural model}

\begin{tabular}{clll}
\hline Construct & $\mathrm{R}^{2}$ & $\mathrm{Q}^{2}$ & $\mathrm{f}^{2}$ \\
\hline ENT & .566 & .284 & .413 \\
FIN & .495 & .252 & .153 \\
MNG & .577 & .264 & .269 \\
GOV & .610 & .311 & .304 \\
INFO & .492 & .319 & .410 \\
MKT & .719 & .339 & .377 \\
PROC & .801 & .450 & .347 \\
SOCIO & .649 & .392 & .290 \\
\hline
\end{tabular}

Note. Elaborated by the authors.

After analyzing the indicators, the bootstrapping module was used to assess whether the correlation relationships (between observed and latent variables) and regression relationships (between latent variables) are significant, i.e., if the p-values are smaller than 0.05 . We calculated the p-values using MS Excel, with the function: "=TDIST(t-value, df; tails)" (Hair et al., 2014). In all cases (correlation and regression relationships), the values observed were above those specified. See Table 5 for detailed results of hypothesis test.

Finally, after adjusting the model, the path coefficients were read. Figure 3 shows the final result of the analyses with 36 of the 43 original items in the questionnaire. Only one EXT-INF path coefficient showed a value of 0.63 . All the remaining ones showed values greater than 0.70 , indicating that the relationships between the model's latent variables are strong, and that it is thus validated. 


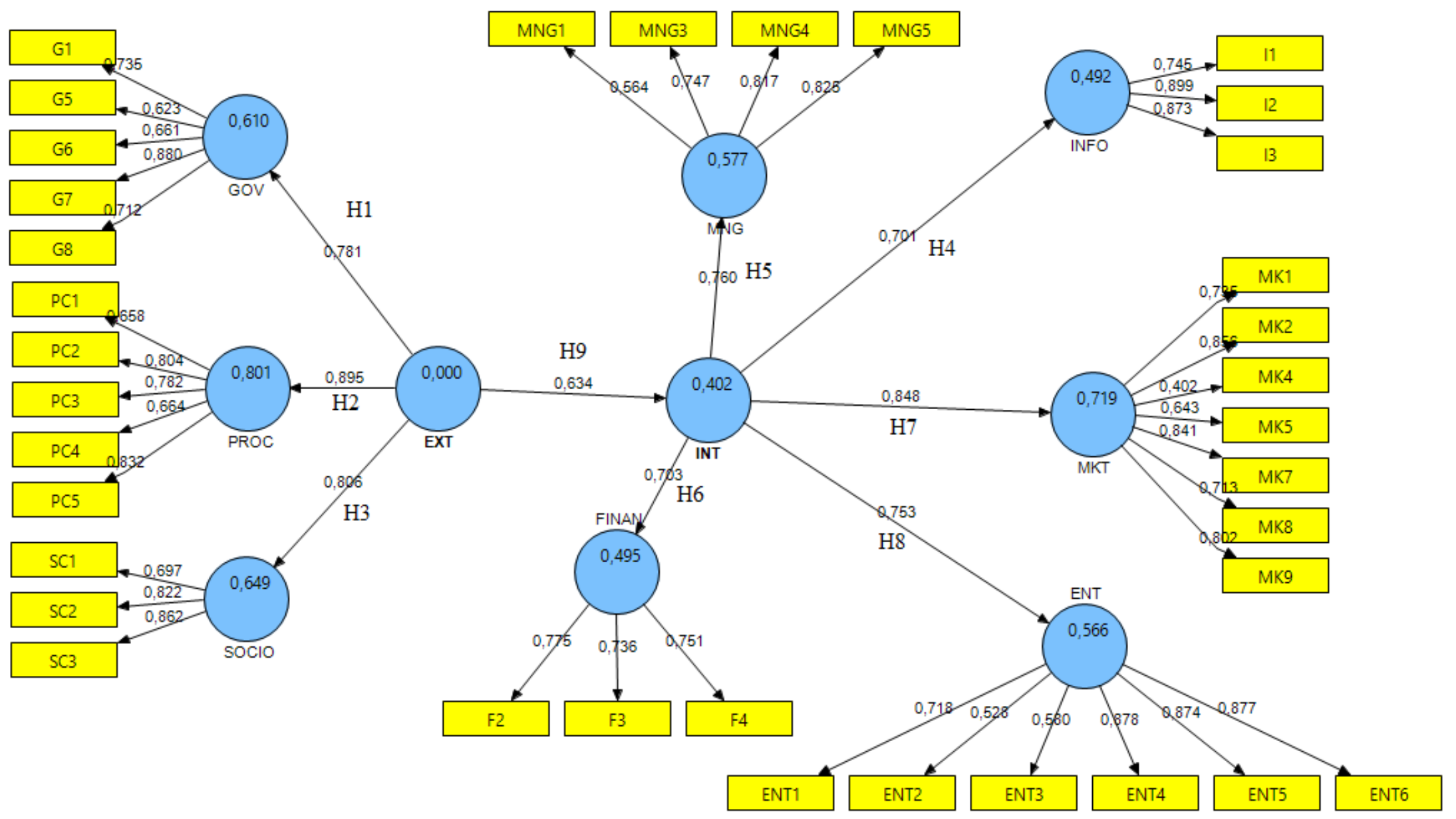

Figure 3. Final adjusted model.

Elaborated by the authors. 
Table 5

Results of the hypotheses test of the structural model

\begin{tabular}{clccc}
\hline Hypothesis & \multicolumn{1}{c}{ Description } & t-test value & p-value & Result \\
\hline H1 & EXT $\rightarrow$ GOV & 56172 & $1.20 \mathrm{E}-269$ & supported \\
H2 & EXT $\rightarrow$ PROC & 147279 & $6.10 \mathrm{E}-299$ & supported \\
H3 & EXT $\rightarrow$ SOCIO & 80261 & $1.70 E-280$ & supported \\
H4 & INT $\rightarrow$ INFO & 20644 & $1.50 E-256$ & supported \\
H5 & INT $\rightarrow$ MNG & 71028 & $9.00 E-277$ & supported \\
H6 & INT $\rightarrow$ FINAN & 39299 & $8.90 E-259$ & supported \\
H7 & INT $\rightarrow$ MKT & 61053 & $3.60 E-272$ & supported \\
H8 & INT $\rightarrow$ ENT & 52169 & $2.20 \mathrm{E}-267$ & supported \\
H9 & EXT $\rightarrow$ INT & 29827 & $2.20 \mathrm{E}-250$ & supported \\
\hline
\end{tabular}

Note. The fourth column ( $p$-value) shows the values in scientific notation format.

\section{A practical application}

To test the model, a sample composed of those who participated in the instrument's validation was asked to check any of the response options (already tried to export, but without success; already exported in the past, but no longer exports; exports, but not frequently; and frequently exports) referring to the question: "Do you export?" Out of the 71 initial companies, 51 participated in this stage. Additionally, of the total 63 SMEs from the City Jewelry Association of Limeira (a city with the biggest cluster in jewelry in São Paulo state) were also invited to participate. Thirty-eight did not export, and of the remaining 25 that did, 44\% (11) answered the questionnaire of the validated model. Thus, the final sample - to which the validated model was applied to analyze the respondents' perception regarding the barriers to exporting process consisted of 67 companies. Brazil is in the $15^{\text {th }}$ position in the global marketplace of jewelry and bijoux.

The following set of information supports the analyses. First, Figure 4 presents the boxplot graph of the eight barriers to exporting, separated in external and internal barriers. Figure 4 presents the minimum, maximum, and mean values, as well as the values of the first, second (median), and fourth quartiles.

Table 6 refers to the dimension of external barriers to exporting, and Table 8 to the dimension of internal barriers. To facilitate understanding, the variation coefficient was used as a measure of dispersion due to the ease of visualization (ranges from 0\% to 100\%). 


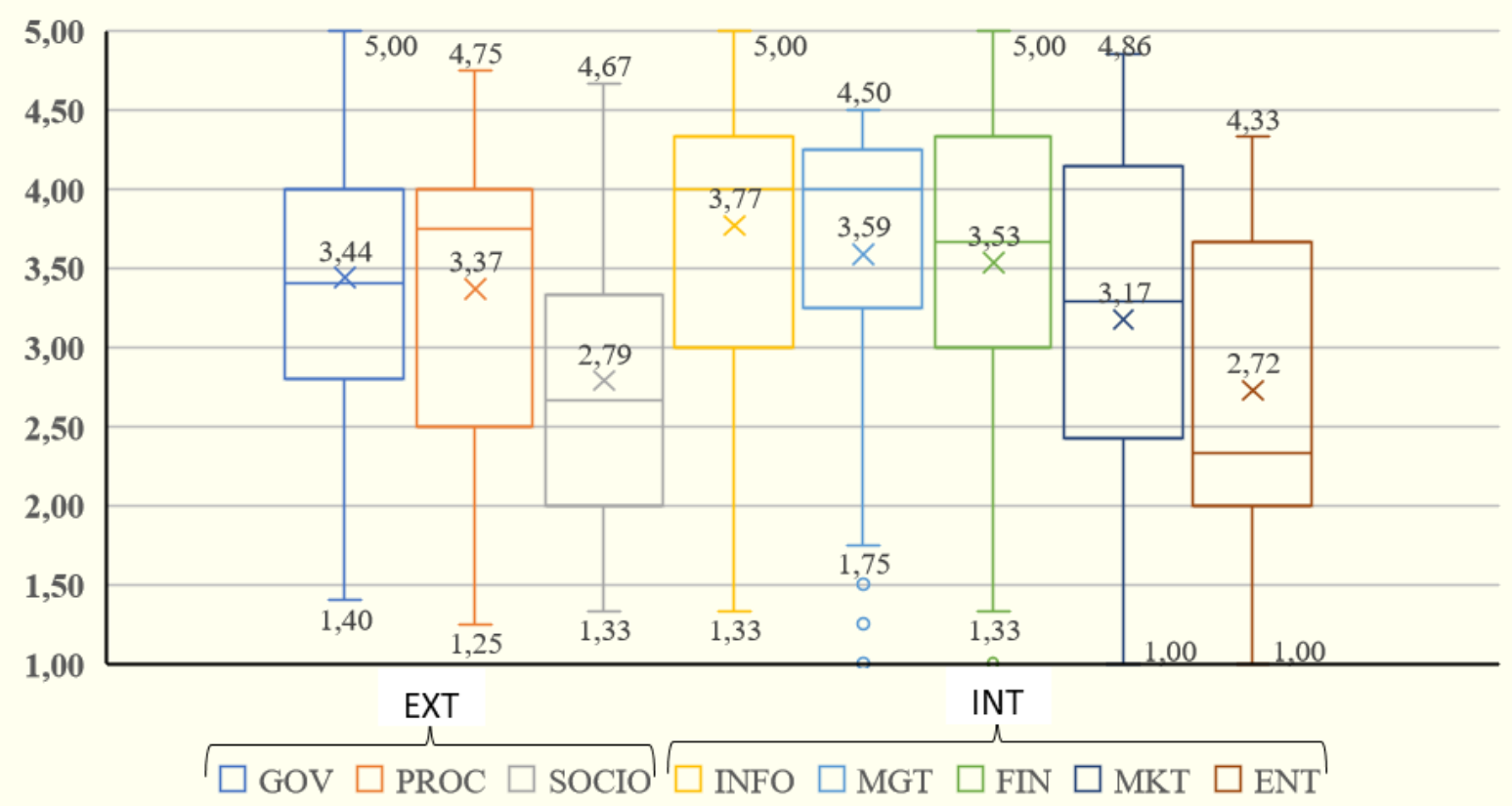

Figure 4. Boxplot of the dimensions of the barriers to export.

\section{External barriers to exporting process}

The analyses related to external barriers to exporting (GOV, PROC, and SOCIO) are based on the evidence contained in Table 6 . As can be seen by the indicators used (Table 4), all three dimensions have non-normal distribution by the Kolmogorov-Smirnov test, although the asymmetry and kurtosis values do not exceed their critical values for a $5 \%$ alpha $(+/-1.96)$. As the constructs did not strictly follow a normal distribution, the mean, median, and coefficient of variation were used for the analysis of the respondents' perceptions.

Table 6

External barriers to export and their items (in the questionnaire)

\begin{tabular}{llc}
\hline Construct / Item & Mean & Coef. of Var. (\%) \\
\hline GOV - Political/economic/legal barriers & 3.66 & 33.2 \\
G1 - Lack of government assistance and incentives & 2.93 & 52.0 \\
G5 - Political instability in foreign markets & 4.03 & 22.0 \\
G6 - Political instability in my country & 3.43 & 41.3 \\
G7 - Corruption in customs control bodies & 3.15 & 47.0 \\
G8 - Lack of seriousness in government promotion actions & & \\
\hline
\end{tabular}




\section{Table 6 (Continued)}

\begin{tabular}{llc}
\hline Construct / Item & Mean & Coef. of Var. (\%) \\
\hline PROC - Procedural and monetary barriers & 3.39 & 43.3 \\
PC1 - Exchange rate fluctuations & 3.40 & 40.6 \\
PC2 - Difficulty collecting taxes abroad & 3.06 & 42.1 \\
PC3 - Complexity of export documentation requirements & 3.63 & 32.8 \\
PC4 - Inadequate communication with customers abroad & & 37.9 \\
\hline SOCIO - Sociocultural barriers & 3.19 & 47.4 \\
SC1 - Acute competition in export markets & 2.91 & 53.1 \\
SC2 - Language differences abroad & 2.25 \\
SC3 - Sociocultural differences (religion, values, customs, attitude, etc.) & \\
\hline
\end{tabular}

Using the mean, we can note that the greater perception of external barriers to exporting is due to the GOV (3.44) construct, followed by the PROC (3.37) and SOCIO (2.79) constructs. As the distribution does not approach a normal one (Table 6), using the median would lead to an inversion between the GOV (3.40) and PROC (3.75) constructs. Therefore, in the perception of the respondents, of the external barriers, the ones that most interfere are procedural and monetary (PROC) and political/economic/legal issues (GOV). The SOCIO construct, however, regardless of the point of view from which it was analyzed (mean or median), remains in the third position of importance.

In relation to the items (Table 6) that make up these two constructs, the indicators that require the most attention are G6 (political instability in my country) and PC4 (inadequate communication with customers abroad), as factors that hinder the export process. The respondents believe both factors can also be considered representative and significant, as they have the lowest coefficients of variation, of $22 \%$ and $33 \%$, respectively.

Finally, although the SOCIO construct (sociocultural barriers), as a whole, is not relevant for the most part, its SC1 indicator (acute competition in export markets) can be highlighted, as it has a mean value of 3.19. It is important to note that items from the set of commonsense knowledge of the business world, such as SC2 (language differences) and SC3 (sociocultural differences: religion, values, customs, attitude), were not found to be important barriers to the exporting from a scientific point of view and with the sample used.

\section{Internal barriers to exporting}

From the analysis of the boxplot graph (Figure 4) and the measures of central tendency, we can infer that the INFO (informational) and MNG (management) constructs are the barriers that

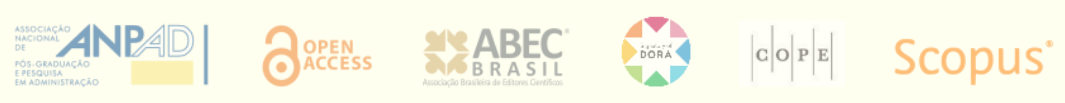


most hinder the export process of the companies in the sample. Both have similar means $(3.77$ and 3.59) and identical medians (4.00).

These two constructs must be a priority of intervention and improvement strategies. As for the rest, the FIN (financial) and MKT (market) constructs are in an intermediate position, and the ENT (entrepreneurship) construct is the least impactful of all, with a mean and median of 2.33. Despite of that, ENT is a new dimension considered in this context.

Looking at Table 8, items I2 (difficulty identifying and contacting potential customers) and GT2 (inadequate/inexperienced export personnel) stand out as factors that hinder the export process of SMEs. These two items are those with the lowest coefficients of variation $(29 \%$ and $27 \%$, respectively), among all items of these two constructs, ensuring their representativeness. In addition to these, item I3 (difficulties gaining access to data sources) is also worth mentioning, with a mean of 3.84 and a variation coefficient of $30 \%$.

In a second step, in the FIN (financial) and MKT (markets) constructs, the items that stand out are F2 (lack of financial resources), with a mean of 3.76, and MK5 (difficulty offering adequate after-sale services), with a mean of 3.67. In the ENT (entrepreneurship) construct, the highlight is E4 (lack of technological innovation). Although the respondents disregard technological innovation as a competitive strategy, national research on it - following the same theoretical and methodological framework as the guidelines in Oslo's Manual (Organisation for Economic Cooperation and Development [OECD], 2018) - shows that this is one of the weak points of the Brazilian technology and science system, with the innovation rate of the 'Manufacture of jewelry, bijouterie, and similar products' being significantly worse than that of the entire manufacturing industry, as shown in Table 7. Differently from the study by Cahen et al. (2016), the present work did not measure the barriers in technology-based firms.

Table 7

Innovation rate* by selected sectors

\begin{tabular}{clllll}
\hline Activity & & 2011 & 2014 & 2017 \\
\hline C. & Manufacturing & 35.9 & 36.3 & 34.3 & 39.9 \\
C. 32 & Others & 39.9 & 39.9 & 27.9 \\
\hline
\end{tabular}

Note. Source: IBGE. Retrieved from https://sidra.ibge.gov.br/tabela/5018 on September 9, 2020. Included: C32.1 — Manufacture of jewelry, bijouterie, and similar products ${ }^{\star *}$; C32.2 - Manufacture of musical instruments; C32.3 - Manufacture of sports goods; C32.4 - Manufacture of games and toys; C32.9 - Manufacturing N.E.C. (not elsewhere classified); Excluded: C32.5 Manufacture of medical and dental instruments and supplies. ${ }^{*}$ Innovation rate: number of companies that reported having introduced new or significantly improved products or services in the last three years prior to the survey, measured as a percentage of the total. ${ }^{* *}$ Based on the International Standard Industrial Classification (ISIC) or the Statistical Classification of Economic Activities in the European Community (NACE) $=32.1$. 
Table 8

Internal barriers to exporting and their items (in the questionnaire)

\begin{tabular}{|c|c|c|}
\hline Construct/Item & Mean & Coef. of Variation (\%) \\
\hline \multicolumn{3}{|l|}{ INFO - Informational barriers } \\
\hline I1 - Insufficient information on foreign markets & 3.49 & 39.0 \\
\hline 12 - Difficulty identifying and contacting potential customers & 3.97 & 29.4 \\
\hline I3 - Difficulties gaining access to data sources & 3.84 & 30.0 \\
\hline \multicolumn{3}{|l|}{ MNG - Management barriers } \\
\hline GT1 - Lack of time to deal with exports & 3.60 & 34.6 \\
\hline GT2 — Inadequate/inexperienced export personnel & 4.03 & 26.6 \\
\hline GT4 - Lack of time and personnel & 3.54 & 31.6 \\
\hline GT5 - Lack of production capacity & 3.18 & 45.5 \\
\hline \multicolumn{3}{|l|}{ FIN - Financial barriers } \\
\hline F2 - Lack of financial resources to finance exports & 3.76 & 35.9 \\
\hline F3 - Difficulty giving credit to customers in international markets & 3.58 & 30.8 \\
\hline F4 - Long liquidity period when receiving payment from abroad & 3.25 & 38.7 \\
\hline \multicolumn{3}{|l|}{ MKT - Market barriers } \\
\hline MK1 - Difficulty adapting export products & 2.72 & 50.8 \\
\hline MK2 - Difficulty meeting export quality requirements & 2.81 & 53.1 \\
\hline MK4 - Complexity of foreign distribution channels & 3.43 & 38.4 \\
\hline MK5 - Difficulty offering adequate after-sale services & 3.67 & 37.4 \\
\hline MK7 - Difficulty exporting to countries where the company has no warehouse & 3.52 & 41.5 \\
\hline MK8 - High transportation cost / lack of transportation quality & 3.34 & 45.0 \\
\hline MK9 - High cost of international insurance & 2.73 & 50.4 \\
\hline \multicolumn{3}{|l|}{ ENT - Barriers to entrepreneurship } \\
\hline E1 - Lack of technological innovation in the company & 3.40 & 41.3 \\
\hline E2 - Lack of vocation for internationalization & 2.51 & 52.1 \\
\hline E3 - Relationship conflicts in family business & 2.09 & 61.1 \\
\hline E4 - Lack of control in new operations & 2.85 & 47.4 \\
\hline E5 - Risk aversion & 2.69 & 51.9 \\
\hline E6 - Difficulty transferring responsibilities when the subject is new & 2.81 & 53.1 \\
\hline
\end{tabular}

\section{DISCUSSION}

To clarify the matter, the first contribution of this work is that the model here presented means an advance in the study of the export process both for scholars and for practitioners. We consider internal and external aspects, adding a new human aspect (managerial/entrepreneurial dimensions) to the previous models and studies. The latter concerns Acedo and Galán (2011). The theory of internationalization supports the constructs, and the model could be tested in the SME's export sector. This paper helps evolve the theory of the internationalization process by

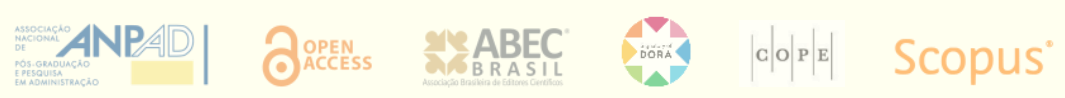


referring to the Acedo and Galán's (2011) work in the context of combined barriers that hinder internationalization.

The hypotheses tested by Acedo and Galán (2011) refer to some characteristics of the TPB, as personal characteristics of the manager (cognitive style, proactiveness, and tolerance to ambiguity) considered in export stimuli. In our paper, we focus on the barriers (and not the export stimuli itself) and we consider the decision-maker characteristics willing to block internationalization (as risk aversion, for example). We used risk aversion as a lack of tolerance of ambiguity and managerial/entrepreneurial barriers as a lack of proactiveness. We did not consider cognitive style. Then, we did not replicate the same Acedo and Galán's (2011) characteristics, but we added barriers to the entrepreneur (H8) and barriers for the management of the firm (H5), as lack of vocation, lack of experience, lack of technological innovation, and lack of time. Emphasizing the 'lacks,' we recall Luostarinen's concept (1979) of 'lateral rigidity' (as lack of international experience, risk aversion, and poor preparedness) in a new context of an emerging economy. Lack of resources and poor institutional support emphasize the importance of RBV and the institutional approach.

The second contribution of this work is the focus on the non-tech-based EM-SME. Most companies from emerging countries are non-tech based. In this sense, the model can be very well suited to countries that are not driven by innovation.

According to the latest estimate available, calculated by the Brazilian Micro and Small Business Support Service (Sebrae), micro-, small, and medium-sized enterprises (MSMEs) represent a universe of 5 million companies, of which only 15,428 have already exported (Fonseca, 2018).

Statistics on the contribution of SMEs to Brazilian exports reveal one of the greatest challenges: while they correspond to $71 \%(15,428)$ of the companies that export, their share in the total export value, equal to US\$217,528 million, is only 3.3\% (US\$ 7,352 million). This reveals the difficulty in densifying productive activities with greater added value and the barriers faced by SMEs in their export processes, many of them related to the initiation, development, and support of operations in foreign markets. This aspect can be seen in many other emerging countries.

The weaknesses of the SME's export sector were exposed: procedural, monetary, political/economic/legal issues can hinder the export process as external barriers. Besides, internal barriers point out inadequate communication with customers abroad, and informational and management issues. This also reinforces to managers the practical implication regarding the biggest difficulties and barriers.

Concerning the contribution to public policy, we disagree with Leonidou's (2000) findings considering that export promotion programs should primarily target the companies that lack networking, non-regular exports, and act as a passive exporter. In the EM, there is a lack of resources and better allocation of public resources should help the companies that are willing to export. The other ones, mentioned by Leonidou (2000), are too far from the target of the export market and too many resources are required to convert those firms in export ones. We emphasize

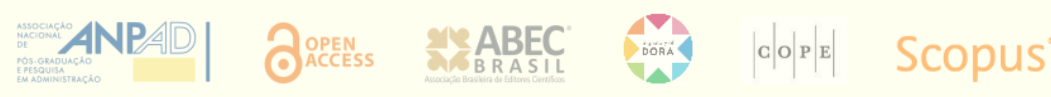


that export programs should take advantage of the willingness of the firm to export. Needless to say, additional aspects, as the currency devaluation in the most EM, add a catalyst effect that naturally contributes to the export process.

Unlike the study by Cahen et al. (2016), which focused on the high-tech industry, this paper focuses on EM-SMEs that are not from the technology-based sector. While Cahen et al.'s results show that institutional, organizational capabilities, and human resource barriers hinder the internationalization process, in our study, the main barriers are related to the government, management, and information. The latter did not appear in Cahen et al.'s (2016) study, especially due to the assumption that tech-based companies are supposed to have expertise in this aspect.

Chandra et al. (2020) state that the internationalization from developing countries differs from the developed ones. The same is stated out by Yener, Doğruoğlu and Ergun (2014). Chandra et al. (2020) list problems like lack of resources and capabilities, managerial incompetence, smallness, economic conditions, knowledge gaps, currency fluctuations, and country-level antecedents and barriers regarding marketing, institutions, export-procedures, environment, human resource, and industry entry and exit. Chandra et al. (2020) develop a dynamic model concerning the EM-SMEs' propensity to internationalize. Our paper goes beyond Chandra's findings because the work of Chandra et al. (2020) have not been tested in any emerging market. Our model was tested and analyzed considering the Brazilian context.

\section{FINAL REMARKS}

This study contributes to the understanding of the barriers (internal and external) to the export process of EM-SMEs. Previous studies on export stimuli and barriers are used, such as the one by Acedo and Galán (2011), which emphasizes the former, and the ones by Al-Hyari et al. (2012), Senik et al. (2014), Roy et al. (2016), and Revindo et al. (2019), which focus on the latter, based on evidence obtained in Jordan, Malaysia, Indonesia, Czech Republic, and India.

The research was validated, and the research questions were answered, regarding the barriers that influence the export process of EM-SMEs. None of the hypotheses was rejected. It is important to mention that, based on previous studies such as those by Leonidou (2004), Al-Hyari et al. (2012), and Roy et al. (2016), a new construct related to the human dimension (of the manager) was added, namely, the entrepreneurship (ENT) construct, which showed high importance for the model as a whole $\left(f^{2}=0.413\right)$.

Previous studies that mention this dimension include those by Acedo and Galán (2011), Cahen et al. (2016), and Amorós et al. (2016), but did not consider the first ones. By adding the human dimension to the previous constructs, a novel model was developed and validated in the reality of non-tech-based EM-SMEs.

Combining the 'what' (which constructs should be considered as part of this model?) and the 'how' (a set of related factors analyzed), a new model was built, from which hypotheses were

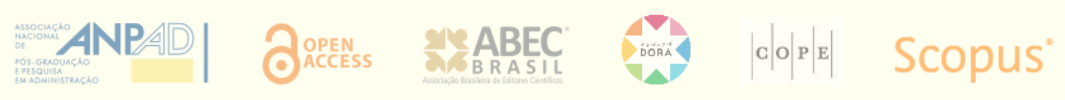


supported. This process is presented by Whetten (1989), as a theoretical contribution. It is also part of the feedback loop.

The research was limited to analyzing the barriers that impact foreign trade, with a focus on EMSMEs. The proposed model was tested in one of the most representative export regions in South America, and validated in the specific sector, one with low technological intensity, as is the case for the vast majority of EM-SMEs. As the study was confined to a single developing country, it is a limitation, as well as the single informant source from each surveyed firm, which could be subject to misunderstanding or bias. Brazil is on the top-15 economies in the world, but with economic constraints and relatively poor GNP per capita.

Suggestions for future studies include the validation of this model in other sectors and industrial segments, in-depth interviews, longitudinal analyses, and the analysis of export regularity across the years, including other emerging countries' samples. The comparison among findings from other emerging countries may contribute to understanding which dimension presents the biggest obstacles in specific contexts. Bringing out the obstacles is a required process for the preparedness of public policies and/or managerial training.

Another limitation is that we did not explore the platform business model for EM-SMEs. This can be an alternative to the export process through a tech platform as a digital business. Non-tech companies can also reach the international market through internet-based technology, even though they are not considered tech companies.

Notwithstanding the limitation of this study, some conclusions can be drawn. First, the model developed in this study can be useful to analyze the barriers to exporting process of EM-SMEs, thus contributing to the theoretical development of the subject in question, providing knowledge on the issue of barriers. Second, it also has practical value, being useful for the proposition of public policies and for small entrepreneurs, because, by identifying the aspects that can hinder the export process, it exposes the biggest barriers, so they can be targeted by actions and policies seeking to minimize them.

\section{REFERENCES}

Acedo, F. J., \& Galán, J. L. (2011). Export stimuli revisited: The influence of the characteristics of managerial decision makers on international behaviour. International Small Business Journal: Researching Entrepreneurship, 29(6), 648-670. https://doi.org/10.1177/0266242610375771

Al-Hyari, K., Al-Weshah, G., \& Alnsour, M. (2012). Barriers to internationalisation in SMEs: Evidence from Jordan. Marketing Intelligence E Planning, 30(2), 188-211. https://doi.org/10.1108/02634501211211975

Amorós, J. E., Basco, R., \& Romaní, G. (2016). Determinants of early internationalization of new firms: The case of Chile. International Entrepreneurship and Management Journal, 12(1), 283-307. https://doi.org/10.1007/s11365. 014-0343-2

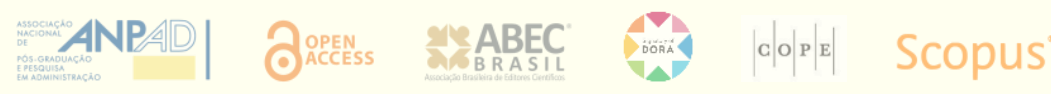


Arroteia, N., \& Hafeez, K. (2021). The internationalisation of TechnoLatinas from a resource-based perspective. International Journal of Entrepreneurial Behaviour E Research, 27(3), 688-710. https://doi.org/10.1108/IJEBR-08. 2019-0472

Barney, J. (1991). Firm resources and sustained competitive advantage. Journal of Management, 17(1), 99-120. https://doi.org/10.1177/014920639101700108

Bianchi, C., Carneiro, J., \& Wickramasekera, R. (2018). Internationalisation commitment of emerging market firms: A comparative study of Chile and Brazil. Journal of Small Business and Enterprise Development, 25(2), 201-221. https://doi.org/10.1108/JSBED-07-2017-0221

Buse, S., Tiwari, R., \& Herstatt, C. (2010). Global innovation: an answer to mitigate barriers to innovation in small and medium-sized enterprises? International Journal of Innovation and Technology Management, 7(3), 215-227. https://doi.org/10.1142/S0219877010001970

Cahen, F. R., Lahiri, S., \& Borini, F. M. (2016). Managerial perceptions of barriers to internationalization: An examination of Brazil's new technology-based firms. Journal of Business Research, 69(6), 1973-1979. https://doi.org/10.1016/j.jbusres.2015.10.143

Caiazza, R. (2016). Internationalization of SMEs in high potential markets. Trends in Food Science Eु Technology, 58, 127-132. https://doi.org/10.1016/j.tifs.2016.10.002

Cardoza, G., \& Fornes, G. (2011). The internationalisation of SMEs from China: The case of Ningxia Hui autonomous region. Asia Pacific Journal of Management, 28(4), 737-759. https://doi.org/10.1007/s10490-009. 9174-z

Castaño, M.-S., Méndez, M.-T., \& Galindo, M.-Á. (2016). Innovation, internationalization and business-growth expectations among entrepreneurs in the services sector. Journal of Business Research, 69(5), 1690-1695. https://doi.org/10.1016/j.jbusres.2015.10.039

Chandra, A., Paul, J., \& Chavan, M. (2020). Internationalization barriers of SMEs from developing countries: A review and research agenda. International Journal of Entrepreneurial Behaviour E Research, 26(6), 1281-1310. https://doi.org/10.1108/IJEBR-03-2020-0167

Ciravegna, L., Majano, S. B., \& Zhan, G. (2014). The inception of internationalization of small and medium enterprises: The role of activeness and networks. Journal of Business Research, 67(6), 1081-1089. https://doi.org/10.1016/j.jbusres.2013.06.002

Cohen, J. (1992). A power primer. Psychological Bulletin, 112(1), 155-159. https://doi.org/10.1037//0033. 2909.112.1.155

Cohen, J. (1988). Statistical power analysis for the behavioral sciences (2 ed.). New York: Routledge.

Cohen, J. (1962). The statistical power of abnormal-social psychological research: A review. The Journal of Abnormal and Social Psychology, 65(3), 145-153. https://doi.org/10.1037/h0045186

Comex Stat (2020). ComexVis. Retrieved from http://comexstat.mdic.gov.br/pt/comex-vis

Colapinto, C., Gavinelli, L., Zenga, M., \& Gregorio, A. D. (2015). Different approaches to the pursuit of internationalization by Italian SMEs. Journal of Research in Marketing and Entrepreneurship, 17(2), 229-248. https://doi.org/10.1108/JRME-11-2014-0030

Dabić, M., Maley, J., Dana, L.-P., Novak, I., Pellegrini, M. M., \& Caputo, A. (2020). Pathways of SME internationalization: A bibliometric and systematic review. Small Business Economics, 55(3), 705-725. https://doi.org/10.1007/s11187-019-00181-6

Deuba, Y. (2015). Export barriers to internationalization: An investigation on Nepalese handmade paper industries (Master thesis). University of Nordland, Master of Science in Business, Bodø, Norway. Retrieved from http://hdl.handle.net/11250/2385443

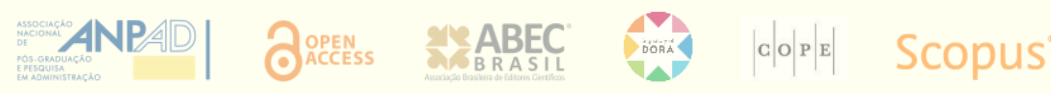


Doh, J., Rodrigues, S., Saka-Helmhout, A., \& Makhija, M. (2017). International business responses to institutional voids. Journal of International Business Studies, 48(3), 293-307. https://doi.org/10.1057/s41267-017-0074-z

Etzkowitz, H., \& Gullbrandsen, M. (1999). Public entrepreneur: the trajectory of United States science, technology and industrial policy. Science and Public Policy, 26(1), 53-62. Retrieved from https://ideas.repec.org/a/oup/scippl/v26y1999i1p53-62.html

Fonseca, P. J. P. (2018). As micro e pequenas empresas nas exportações brasileiras: 2009-2017. Brasília, DF: SEBRAE. Retrieved from https://datasebrae.com.br/wp-content/uploads/2018/11/As-Micro-e-Pequenas-Empresas-nasExporta\%C3\%A7\%C3\%B5es-Brasileiras-2009-2017-Brasil-VF.pdf

Fornell, C., \& Larcker, D. F. (1981). Evaluating structural equation models with unobservable variables and measurement error. Journal of Marketing Research, 18(1), 39-50. https://doi.org/10.2307/3151312

Fuller, C. M., Simmering, M. J., Atinc, G., Atinc, Y., \& Babin, B. J. (2016). Common methods variance detection in business research. Journal of Business Research, 69(8), 3192-3198. https://doi.org/10.1016/j.jbusres.2015.12.008

Gardó, T. F., García, H. C., \& Descals, A. M. (2015). Internationalization of SME retailer: Barriers and the role of public support organizations. International Journal of Retail EF Distribution Management, 43(2), 183-200. https://doi.org/10.1108/IJRDM-07-2013-0146

Hair, J. F., Black, W. C., Babin, B. J., \& Anderson, R. E. (2010). Multivariate data analysis (7 ed.). London: Pearson.

Hair, J. F. J., Hult, G. T. M., Ringle, C. M., \& Sarstedt, M. (2014). A primer on partial least squares structural equation modeling (PLS-SEM). Thousand Oaks, CA: SAGE.

Hessels, J., \& Parker, S. C. (2013). Constraints, internationalization and growth: A cross-country analysis of European SMEs. Journal of World Business, 48(1), 137-148. https://doi.org/10.1016/j.jwb.2012.06.014

Hosseini, S., Fallon, G., Weerakkody, V., \& Sivarajah, U. (2019). Cloud computing utilization and mitigation of informational and marketing barriers of the SMEs from the emerging markets: Evidence from Iran and Turkey. International Journal of Information Management, 46, 54-69. https://doi.org/10.1016/j.ijinfomgt.2018.11.011

Jafari-Sadeghi, V., Mahdiraji, H. A., Bresciani, S., \& Pellicelli, A. C. (2021). Context-specific micro-foundations and successful SME internationalisation in emerging markets: A mixed-method analysis of managerial resources and dynamic capabilities. Journal of Business Research, 134, 352-364. https://doi.org/10.1016/j.jbusres.2021.05.027

Kahiya, E. T. (2017). Export barriers as liabilities: Near perfect substitutes. European Business Review, 29(1), 61-102. https://doi.org/10.1108/EBR-12-2015-0160

Kamakura, W. A., Ramón-Jerónimo, M. A., \& Gravel, J. D. V. (2012). A dynamic perspective to the internationalization of small-medium enterprises. Journal of the Academy of Marketing Science, 40(2), 236-251. https://doi.org/10.1007/s11747-011-0267-0

Kozlova, A. (2014). Internationalization process of SMEs: Motives and barriers - case study of "Taste of North" (Master thesis). University of Nordland, Bodø Graduate School of Business, Bodø, Norway.

Krakawer, P. V. C., Jussani, A. C., \& Vasconcellos, E. P. G. (2013). A utilização de alianças estratégicas na internacionalização de pequenas e médias empresas: Estudo de caso em uma empresa brasileira de tecnologia da informação. REGE - Revista de Gestão, 20(3), 299-311. Retrieved from http://www.spell.org.br/documentos/ver/30627/a-utilizacao-de-aliancas-estrategicas-na-internacionalizacao-depequenas-e-medias-empresas-estudo-de-caso-em-uma-empresa-brasileira-de-tecnologia-da-informacao/i/pt-br

Kuivalainen, O., Sundqvist, S., Saarenketo, S., \& McNaughton, R. (2012). Internationalization patterns of small and medium-sized enterprises. International Marketing Review, 29(5), 448-465. https://doi.org/10.1108/02651331211260331

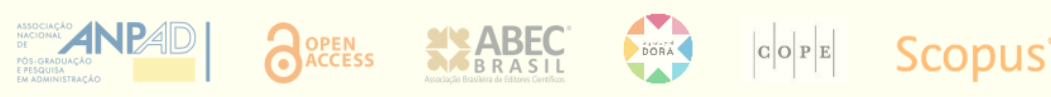


Kunday, Ö., \& Şengüler, E. P. (2015). A study on factors affecting the internationalization process of small and medium enterprises (SMEs). Procedia - Social and Behavioral Sciences, 195, 972-981. https://doi.org/10.1016/j.sbspro.2015.06.363

Lejárraga, I., \& Oberhofer, H. (2015). Performance of small- and medium-sized enterprises in services trade: Evidence from French firms. Small Business Economics, 45(3), 673-702. https://doi.org/10.1007/s11187-015-9647-z

Leonidou, L. C. (2000). Barriers to export management: An organizational and internationalization analysis. Journal of International Management, 6(2), 121-148. https://doi.org/10.1016/S1075-4253(00)00022-3

Leonidou, L. C. (2004). An analysis of the barriers hindering small business export development. Journal of Small Business Management, 42(3), 279-302. https://doi.org/10.1111/j.1540-627X.2004.00112.x

Leonidou, L. C., Katsikeas, C. S., \& Piercy, N. F. (1998). Identifying managerial influences on exporting: Past research and future directions. Journal of International Marketing, 6(2), 74-102. https://doi.org/10.1177/1069031x9800600209

Liang, H., Saraf, N., Hu, Q., \& Xue, Y. (2007). Assimilation of enterprise systems: The effect of institutional pressures and the mediating role of top management. MIS Quarterly, 31(1), 59-87. https://doi.org/10.2307/25148781

Luo, Y., \& Tung, R. L. (2007). International expansion of emerging market enterprises: A springboard perspective. Journal of International Business Studies, 38(4), 481-498. https://doi.org/10.1057/palgrave.jibs.8400275

Luostarinen, R. (1979). Internationalization of the firm: An empirical study of the internationalization of firms with small and open domestic markets with special emphasis on lateral rigidy as a behavioral characteristics in strategic decision making. Helsinki: The Helsinki School of Economics.

Makhmadshoev, D., Ibeh, K., \& Crone, M. (2015). Institutional influences on SME exporters under divergent transition paths: Comparative insights from Tajikistan and Kyrgyzstan. International Business Review, 24(6), 10251038. https://doi.org/10.1016/j.ibusrev.2015.02.010

Mendy, J., \& Rahman, M. (2019). Supporting SMEs' internationalisation through a deeper understanding of human and technology barriers: Applying effective HRM processes from a developing country. Journal of Organizational Effectiveness: People and Performance, 6(4), 205-226. https://doi.org/10.1108/JOEPP-12-2018-0121

Meneses, R., Coutinho, R., \& Pinho, J. C. (2014). The impact of succession on family business internationalisation: The successors' perspective. Journal of Family Business Management, 4(1), 24-45. https://doi.org/10.1108/JFBM01-2013-0004

Merino, F., Monreal-Pérez, J., \& Sánchez-Marín, G. (2015). Family SMEs' internationalization: Disentangling the influence of familiness on spanish firms' export activity. Journal of Small Business Management, 53(4), 1164-1184. https://doi.org/10.1111/jsbm.12111

Mohr, A., \& Shoobridge, G. E. (2011). The role of multi-ethnic workforces in the internationalisation of SMEs. Journal of Small Business and Enterprise Development, 18(4), 748-763. https://doi.org/10.1108/14626001111179785

Morgan, R. E. (1997). Export stimuli and export barriers: Evidence from empirical research studies. European Business Review, 97(2), 68-79. https://doi.org/10.1108/09555349710162571

Narayanan, V. (2015). Export barriers for small and medium-sized enterprises: A literature review based on Leonidou's model. Entrepreneurial Business and Economics Review, 3(2), 105-123. https://doi.org/10.15678/EBER.2015.030208

Organisation for Economic Co-operation and Development (2005). Enterprises by business size. Retrieved from https://data.oecd.org/entrepreneur/enterprises-by-business-size.htm

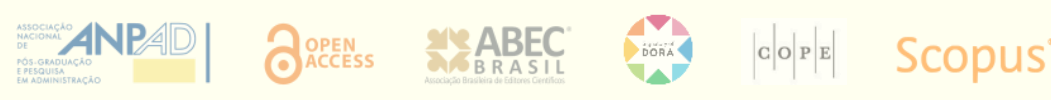


Organisation for Economic Co-operation and Development. (2018). Oslo manual 2018: Guidelines for collecting, reporting and using data on innovation (4 ed.). Paris: OECD, Eurostat. https://doi.org/10.1787/9789264304604en

Oliveira, G. C., Neto, Leite, R. R., Shibao, F. Y., \& Lucato, W. C. (2017). Framework to overcome barriers in the implementation of cleaner production in small and medium-sized enterprises: Multiple case studies in Brazil. Journal of Cleaner Production, 142(Part 1), 50-62. https://doi.org/10.1016/j.jclepro.2016.08.150

Paul, J. (2020). SCOPE framework for SMEs: A new theoretical lens for success and internationalization. European Management Journal, 38(2), 219-230. https://doi.org/10.1016/j.emj.2020.02.001

Plakoyiannaki, E., Kampouri, A. P., Stavraki, G., \& Kotzaivazoglou, I. (2014). Family business internationalisation through a digital entry mode. Marketing Intelligence $\mathcal{E}$ Planning, 32(2), 190-207. https://doi.org/10.1108/MIP. 01-2013-0016

Podsakoff, P. M., MacKenzie, S. B., Lee, J.-Y., \& Podsakoff, N. P. (2003) Common method biases in behavioral research: A critical review of the literature and recommended remedies. Journal of Applied Psychology, 88(5), 879903. https://doi.org/10.1037/0021-9010.88.5.879

Rahman, M., \& Mendy, J. (2019). Evaluating people-related resilience and non-resilience barriers of SMEs' internationalisation: A developing country perspective. International Journal of Organizational Analysis, 27(2), 225240. https://doi.org/10.1108/IJOA-02-2018-1361

Rahman, M., Uddin, M., \& Lodorfos, G. (2017). Barriers to enter in foreign markets: Evidence from SMEs in emerging market. International Marketing Review, 34(1), 68-86. https://doi.org/10.1108/IMR-10-2014-0322

Revindo, M. D., Gan, C., \& Massie, N. W. G. (2019). Factors affecting propensity to export: The case of Indonesian SMEs. Gadjah Mada International Journal of Business, 21(3), 263-288. https://doi.org/10.22146/gamaijb.41022

Roux, I. L., \& Bengesi, K. M. K. (2014). Dimensions of entrepreneurial orientation and small and medium enterprise performance in emerging economies. Development Southern Africa, 31(4), 606-624. https://doi.org/10.1080/0376835X.2014.913474

Roy, A., Sekhar, C., \& Vyas, V. (2016). Barriers to internationalization: A study of small and medium enterprises in India. Journal of International Entrepreneurship, 14(4), 513-538. https://doi.org/10.1007/s10843-016-0187-7

Salvador, E., Villechenon, F. P. de, \& Rizzo, H. L. (2014). European SMEs and the Brazilian market: The key role of social networks. European Business Review, 26(4), 368-388. https://doi.org/10.1108/EBR-10-2013-0129

Schwarz, A., Rizzuto, T., Carraher-Wolverton, C., Roldán, J. L., \& Barrera-Barrera, R. (2017). Examining the impact and detection of the "urban legend" of common method bias. ACM SIGMIS Database: the DATABASE for Advances in Information Systems, 48(1), 93-119. https://doi.org/10.1145/3051473.3051479

Senik, Z. C., Isa, R. M., Sham, R. M., \& Ayob, A. H. (2014). A model for understanding SMEs internationalization in emerging economies. Jurnal Pengurusan (UKM Journal of Management), 41, 25-42. https://doi.org/10.17576/pengurusan-2014-41-03

Shih, T.Y., \& Wickramasekera, R. (2011). Export decisions within Taiwanese electrical and electronic SMEs: The role of management characteristics and attitudes. Asia Pacific Journal of Management, 28(2), 353-377. https://doi.org/10.1007/s10490-010-9213-9

Silver, B. (2003). Country classifications. In Forces of Labor: Workers' movements and globalization since 1870 (Cambridge Studies in Comparative Politics, p. 204). Cambridge: Cambridge University Press. https://doi.org/10.1017/CBO9780511615702.009

Stephen, F. H., Urbano, D., \& Hemmen, S. V. (2005). The impact of institutions on entrepreneurial activity. Managerial and Decision Economics, 26(7), 413-419. https://doi.org/10.1002/mde.1254

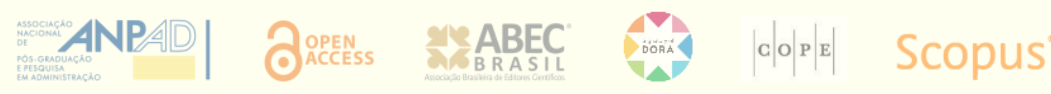


Tan, A., Brewer, P., \& Liesch, P. (2018). Rigidity in SME export commencement decisions. International Business Review, 27(1), 46-55. https://doi.org/10.1016/j.ibusrev.2017.05.002

Yan, H., Wickramasekera, R., \& Tan, A. (2018). Exploration of Chinese SMEs' export development: The role of managerial determinants based on an adapted innovation-related internationalization model. Thunderbird International Business Review, 60(4), 633-646. https://doi.org/10.1002/tie.21969

Yener, M., Doğruoğlu, B., \& Ergun, S. (2014). Challenges of Internationalization for SMEs and overcoming these challenges: A case study from Turkey. Procedia - Social and Behavioral Sciences, 150, 2-11. https://doi.org/10.1016/j.sbspro.2014.09.002

Zhu, Y., Warner, M., \& Sardana, D. (2020). Internationalization and destination selection of emerging market SMEs: Issues and challenges in a conceptual framework. Journal of General Management, 45(4), $206-216$. https://doi.org/10.1177/0306307020903530

Whetten, D. A. (1989). What constitutes a theoretical contribution? The Academy of Management Review, 14(4), 490495. https://doi.org/10.2307/258554

\section{Authors' contributions}

$1^{\text {st }}$ author: conceptualization (lead), project administration (lead), supervision (lead), validation (equal), methodology (equal), writing - original draft (equal), writing - review and editing (equal).

$2^{\text {nd }}$ author: funding acquisition(lead), investigation (equal), resources (equal), writing - original draft (equal).

$3^{\text {rd }}$ author: formal analysis (equal), methodology (equal), visualization (equal), writing - review and editing (equal).

$4^{\text {th }}$ author: conceptualization (equal), formal analysis (equal), methodology (equal), validation (equal), visualization (equal), writing - original draft (equal), writing - review and editing (equal).

\section{Authors}

\section{Cristiano Morini*}

Universidade de Campinas, Faculdade de Ciências Aplicadas

Rua Pedro Zaccaria, n. 1300, Jd. São Paulo, 13484-350, Limeira, SP, Brazil

cristiano.morini@fca.unicamp.br

(iD) https://orcid.org/0000-0003-2868-3280

\section{Mario Cesar Barreto Polis}

Universidade de Campinas, Faculdade de Ciências Aplicadas

Rua Pedro Zaccaria, n. 1300, Jd. São Paulo, 13484-350, Limeira, SP, Brazil

mariocbpolis@gmail.com

(iD) https://orcid.org/0000-0003-4268-6170

\section{Dirceu da Silva}

Universidade de Campinas, Faculdade de Educação, Departamento de Ensino e Práticas Culturais

Rodovia Professor Zeferino Vaz, 13083, Jardim Santa Genebra II (Barao Geraldo), 13082-740, Campinas, SP,

Brazil

dirceuds@gmail.com

(iD) https://orcid.org/0000-0003-3267-511X

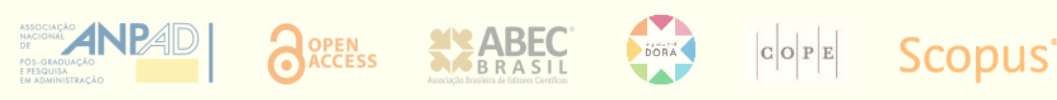




\section{Edmundo Inacio Junior}

Universidade de Campinas, Faculdade de Ciências Aplicadas

Rua Pedro Zaccaria, n. 1300, Jd. São Paulo, 13484-350, Limeira, SP, Brazil

edmundo.inacio@fca.unicamp.br

(iD) https://orcid.org/0000-0003-0137-0778

* Corresponding author

Peer review is responsible for acknowledging an article's potential contribution to the frontiers of scholarly knowledge on business or public administration. The authors are the ultimate responsible for the consistency of the theoretical references, the accurate report of empirical data, the personal perspectives, and the use of copyrighted material.

This content was evaluated using the double-blind peer review process. The disclosure of the reviewers' information on the first page is made only after concluding the evaluation process, and with the voluntary consent of the respective reviewers. 